\title{
Is Education Becoming a Weaker Determinant of Occupation? Educational Expansion and Occupational Returns to Education in 30 European Countries*
}

\author{
TOMÁŠ KATRŇÁK and TOMÁŠ DOSEDĚL** \\ Masaryk University, Brno
}

\begin{abstract}
This article examines the relationship between education and occupation over the course of educational expansion. The authors analyse European Union Labour Force Survey (EU-LFS) data from 2014, 2015, and 2016 from 30 European countries and work with 12 graduated cohorts defined by the year in which they left the education system (2003-2014). They use a multilevel model approach and measure education in both absolute and relative terms. The results show that during the time of educational expansion there was no change in the relationship between education and occupation if education is conceptualised in absolute terms. However, a change in this relationship is visible when education is conceptualised as a positional good. Many previous studies that have posed a similar research question did not consider study field. The results here show that the role of study field changed during this time of educational expansion, with natural science, computer, and IT study fields growing stronger than other fields of study. The authors interpret the strengthening of education as a positional good in reference to the theory of skill-biased technological change.
\end{abstract}

Keywords: education, human capital, positional good, educational expansion, occupation, European countries

Sociologický časopis/Czech Sociological Review, 2019, Vol. 55, No. 6: 821-851

https://doi.org/10.13060/00380288.2020.55.6.493

Sociologists working in the field of social stratification agree that education level is a strong determinant of labour market position in modern societies [Blau and Duncan 1967; Erikson and Goldthorpe 1992; Breen 2004]. Education is considered to be one of the strongest predictors of occupation and income and also of behaviour, values, attitudes, and opinions. Different levels of education then imply different positions in the labour market and different income levels. From this perspective, education is a good that can be utilised. Returns to education are a

\footnotetext{
* This research was supported by the Czech Science Foundation (Grant No. GA19-06326S: 'The Change of the Role of Education in European Labour Markets, 2000-2015').

** Direct all correspondence to: Tomáš Katrňák, Faculty of Social Studies, Masaryk University, Brno, katrnak@fss.muni.cz; Tomáš Doseděl, Faculty of Social Studies, Masaryk University, Brno, dosedel@fss.muni.cz.
} 
topic of interest in sociology. From an economic perspective, a return can be expressed as the ratio between the benefits related to higher education and the costs necessary to obtain it. The returns to education are both individual and social [Dickson and Harmon 2011; Hout 2012]. The individual returns reflect the fact that different levels of education result in different occupations, incomes, and economic security. The social returns describe the social contributions of education, such as the health of the population, life expectancy, the rates of crime and suicides, and the size of the GDP.

This article focuses on the individual returns to education in 30 European countries. Dickson and Harmon [2011] and Vila [2000] distinguish between monetary and non-monetary individual returns to education. Monetary returns are expressed by income; non-monetary returns include the quality of occupation. This analysis concerns non-monetary returns to education; specifically, we analyse the relationship between education and occupation and talk about occupational returns to education. Our analysis focuses on the period between 2003 and 2014, when European countries experienced educational expansions. We focus on the position in the labour market of the people who left the educational system during this time, and we study whether and how the educational expansion influenced their transitions into the labour market. What is the change in the relationship between educational achievement and occupation in the time of educational expansion in Europe? How strongly does education determine occupation during a period of rising education levels? Is this effect stronger or weaker? These are our research questions. ${ }^{1}$

Studies that have recently asked similar questions have shown that one of the consequences of educational expansion is a change in the role of education in the labour market [cf. Rotman, Shavit and Shavel 2016; Fujihara and Ishida 2016; Bol 2015; Ortiz and Rodriguez-Menés 2016]. Education ceases to be an absolute category (nominal) and becomes a relative category (positional good) that is influenced by time and place. In our analysis, we build on these conclusions, and we conceptualise education in absolute as well as in relative terms. In addition, we take into account the fields of study-i.e. the horizontal differentiation of education, which has not been considered in most previous studies. We start from the assumption that the study fields are as important for the school-to-work connection as the level of education. It is known that educational expansion is not universal, but field-specific. The data we analyse were obtained from the European Union Labour Force Survey (EU-LFS) between 2014 and 2016. As the data contain information on graduated cohorts in 30 European countries, we analyse it using multilevel models.

The results support the theory that education is changing into a positional good. The occupational returns to absolute education did not change dramati-

\footnotetext{
1 The answers to these questions in the context of social stratification research, without relation to educational expansion, cf. Shavit and Müller [1998].
} 
cally during the period of educational expansion; the occupational returns to relative education increased. For absolute education, the effect of study fields was diminished by the educational expansion; for relative education, this effect was strengthened by educational expansion. The most significant growth is observed in the field of natural science/computer/IT and engineering/construction. We interpret the change of education to a positional good as a function of the deployment of new technologies, computerisation, and robotisation on the labour market, which increased the demand for employees in these fields, and which provided them with a relative advantage in comparison with other fields (taskbiased technological change theory).

\section{The role of education on the labour market}

Sociologists and economists conceptualise education most commonly as human capital [Barone and Van de Werfhorst 2011]. ${ }^{2}$ In this perspective, education indicates acquired competences that make it possible to work efficiently, i.e. with higher productivity, and obtain an appropriate position in the labour market [Mincer 1958; Becker 1964]. In meritocratic societies, people receive various financial compensations according to their occupation (their different positions in the labour market), and they have different work benefits and social securities. In short, they belong to different social positions [Jackson, Goldthorpe and Mills 2005; Goldthorpe 2014]. According to Becker [1964], these differences happen because the modern labour market works on the economic principle of supply and demand. A higher level of education brings better financial compensation, because in the context of ongoing modernisation processes there is a higher demand for people with such an education. A lower level of education brings lower financial compensation, because there is not such a demand for people with lower levels of education. In this perspective, the monetary and non-monetary benefits of education are determined by the level of education attainment. These benefits are not influenced by the number of people with the same level of education, and these benefits do not change much over time. Credentials have intrinsic value [Mincer 1974; Becker 1964; Kerckhoff, Raudenbush and Glennie 2001]. This is the absolute (nominal) value of education [Rotman, Shavit and Shavel 2015].

Human capital theory originated at a time when the number of tertiary education graduates in the labour market was not changing [Brown 2001]. When sociologists and economists talked about educational expansion, they anticipated two social stratification consequences.

The first consequence is a decrease in unequal chances for education according to social origin. This anticipated consequence is based on the assumption

\footnotetext{
2 The OECD defines human capital as 'the knowledge, skills, competencies and attributes that allow people to contribute to their personal and social well-being, as well as that of their countries' [Keeley 2007: 3].
} 
that, in industrial societies, the labour market rewards only skills (proven by attained education), and not ascriptive characteristics (social origin, gender, age, or ethnicity). Education-based meritocracy theory was formulated on this basis. However, this theory was apparently too optimistic: employers do not make hiring decisions strictly based on the qualification of job applicants; employers also consider applicants' social origins and the soft skills that strongly correlate with social origins. Even though this happens implicitly, this effect of social origin is still valid. Therefore, this theory was replaced by the theory of education as a great equaliser, a theory that anticipates that if the accessibility of education increases due to educational expansion, educational inequalities based on social origin will at least partly decrease [Bernardi and Ballarino 2016].

The second consequence is credential inflation [Berg 1970; Collins 1979, 2002]. If we understand education as an achieved variable that people utilise in the labour market, then its value and its monetary and non-monetary benefits are determined by the relationship between the supply and demand for it. If demand is low and supply is high, the value of education decreases, and vice versa. Therefore, if educational expansion increases the number of people with higher education, while at the same time the number of appropriate job opportunities does not increase, then the monetary and non-monetary benefits of education decrease. Ulrich Beck [2011] stated that a university diploma no longer means automatically getting a good job, but it is a necessary ticket when applying to compete for such a job. Other authors developing the inflation theory have assumed that members of the expanding cohorts of graduates must show additional personal competitive advantages in order to reach similar positions as previous cohorts with an identical level of education [Bourdieu and Passeron 1990; Bourdieu 1996; Van de Werfhorst and Andersen 2005]. Otherwise, graduates must accept less prestigious occupations, while pushing less educated employees out of the labour market [Burris 1983; Kivinen and Ahola 1999; Morrison Paul and Siegel 2001; Nelson and Phelps 1966; Welch 1970].

However, empirical studies from the 1980s showed no inflation in tertiary education [c.f. Card and Dinardo 2002]. One explanation was the increasing use of information technologies across all domains of human activity, which requires a qualified workforce. In response, the theory of skill-biased technological change was formulated in the 1990s. According to this theory, the labour market gives preference to job applicants with higher education, while employees with lower education are excluded from the labour market because their work is outsourced to other countries or is being done by machines [Ábrahám 2008; Blinder 2009; Card and Dinardo 2002; Morrison Paul and Siegel 2001; Oesch 2013]. Berman, Somanathan and Tan [2005] see technology as the main reason for the higher demand for university graduates. Acemoglu [2002] states that technological changes have been taking place since the industrial revolution and divides these changes into two periods. First, the demand for unskilled workers for mass production in factories increased due to Fordism. After the 1950s, thanks mainly to the intro- 
duction of information technology, the demand for highly skilled workers started to increase. While some studies challenge the theory of technological change connected with the persistent demand for people with higher education [cf. Aamodt and Arnesen 1995; Kivinen and Ahola 1999], according to this theory the labour markets of modern societies are not yet saturated with university graduates to the extent that supply outstrips demand. Educational expansion does not mean decreasing the value of education as human capital. Moreover, the polarisation hypothesis - emerging at the beginning of the new millennium-provides empirical evidence that while the income returns to education do indeed increase for workers with tertiary attainment (as expected by the skill-biased technological change theory), they also do so for workers of the lowest attainment due to the growth of the service sector. The labour market becomes polarised [Autor, Levy and Murnane 2003; Manning 2004; Oesch and, Rodriguez Menés 2010]. In our first hypothesis, we therefore expect that the value of education as human capital in a time of educational expansion does not change. The occupational return to absolute education remains constant.

\section{Education as a positional good}

The theory of education as a positional good assumes that the value of education is given contextually [Thurow 1975; Hirsch 1978]. The returns to education are determined by one group of individuals at a given level of education relative to other groups of individuals at the other levels of education. The sociological literature often presents the example of a car: its benefit as a means of transportation from point $\mathrm{A}$ to point $\mathrm{B}$ varies for the user according to the number of cars around. If a majority owns a car, traffic jams result and the benefit of a car decreases [Hirsch 1978; Ultee 1980]. Therefore, owning a car is not a value in itself; rather, the time and place define the value of a car. The value of education as a positional good varies in relation to its scarcity. The value does not come from the level of education alone. In a time of educational expansion, the number of people attaining higher education increases, and the individual return to education can be directly affected by this number. People with the same level of education are in the same position when entering the labour market; however, if their number is larger than the number of relevant job opportunities, the return to higher levels of education can approach that of lower levels of education. Employers start to distinguish among people according to other, 'softer' criteria [Thurow 1975]. According to signalling theory [Arrow 1973; Spence 1973], the level of education is then only one of a set of a person's characteristics (albeit the most important one) for taking up a position in the labour market. Other non-directly observable characteristics include the motivation to work; the ability to learn new things; the ability to express one's opinion; the ability to lead and motivate people, to pursue a certain goal over a longer period, and to be loyal to the work and the employer [Weiss 1995; Jackson, Goldthorpe and Mills 2005; Goldthorpe 2014]. 
The change of education in a positional good can be conceptualised on a macro- as well as a micro-societal level. On the macro level, the benefits of different education levels change. This can happen 'from the bottom' or 'from the top' of the educational structure. In the first case, lower education levels become redundant in the labour market, their returns to education decrease, and higher levels of education thus receive a relative advantage over them. In the second case, the demand for higher levels of education grows thanks to technological changes, while the technology does not change for lower levels. In both cases, the positional advantages for some levels of education are created.

On the micro level, employers create job opportunities connected with specific requirements. For these jobs, they do not expect applicants to have specific knowledge obtained in the education system. On the contrary, they choose candidates who were prepared by the education system to be able to obtain this knowledge after taking up the position. This is expected to happen in the shortest time possible and using the least financial resources possible. The employer has to bear the time and financial burden connected with the imperfect work of an untrained employee. Therefore, it is not the absolute value of education that guarantees a position in the labour market, but the ability, readiness, and facility of a person to successfully master the requirements connected with a particular work position [Goldthorpe 2009]. Job applicants are then lined up by the employer into an imaginary labour queue not only according to the level of education, but also according to a number of other characteristics [Thurow 1975].

The change in the value of education from absolute to relative has been tested by a number of sociological studies [e.g. Ultee 1980; Olneck and Kim 1989; Bol 2015; Bukodi and Goldthorpe 2016; Rotman, Shavit and Shalev 2016; Fujihara and Ischida 2016; Ortiz and Rodriguez-Menés 2016]. Even though these studies focused on different social phenomena; in relation to the monetary or the nonmonetary benefits of education, they share a common question: to what extent is the change in the analysed phenomenon caused by the shift in education from human capital to a positional good? The results show that each concept of education produces different results. While the explanatory potency of education conceptualised in absolute terms decreased, the explanatory power of education as a positional good increased. ${ }^{3}$ Following these conclusions, in our second hypothesis we expect that the value of education, conceptualised as a positional good, increases in a time of educational expansion. The occupational returns to relative education increase.

${ }^{3}$ Cf. the thematic issue of Research in Social Stratification and Mobility 43 (2016), which focuses on the change in the value of education as a positional good, and the effects of this change on social stratification outcomes. 


\section{Educational expansion and the horizontal differentiation of study fields}

In 1999 the Bologna declaration was signed, which can be seen as jumpstarting the most recent wave of educational expansion in Europe. ${ }^{4}$ This declaration recommended that the signatory nations should divide university education into three levels: a widely accessible bachelor's level, a more selective master's (level 5 of the International Standard Classification of Education / ISCED), and a scientific post-graduate level (ISCED level 6)..$^{5}$ The division of five-year master's (magister) degrees into bachelor's and master's levels of study made it possible for universities to substantially open up the education system to a wider range of applicants. As another reason for educational expansion, Kogan [2012] cites the creation of new study fields and new institutions in higher education (private institutions and, particularly, smaller regional ones). For example, in the Czech Republic, the number of higher education institutions increased from 23 in 1999 to 67 in 2015. Private universities started to appear after 2000. By 2015, there were 41 private universities.

Figure 1 shows the course of educational expansion in 30 European countries between 2003 and 2015 for the age group 25 to 34 years. ${ }^{6}$ The x-axis shows the proportion of people with tertiary education in 2003 in each country. The $y$-axis shows how much this proportion increased between 2003 and 2015. The expansion is path dependent and is negatively contingent upon the proportion of people with tertiary education (the Pearson correlation is -0.55). The increase between 2003 and 2015 is lower in countries where the proportion with tertiary education was already higher in 2003, and vice versa. The average proportion of people with tertiary education across countries was $26.5 \%$ in 2003 and $40.4 \%$ in 2015. Among the Western European countries that in 2003 fell below the Euro-

\footnotetext{
${ }^{4}$ The first educational expansion occurred in Western European countries in the 1970s, when the number of university students more than doubled [Trow 1973]. In the statesocialist countries, the class and political affiliations of the parents, as well as the low capacity of universities, limited access to higher education before 1989. Moreover, in these countries, studying at a university was subject to central planning (similar to other aspects of society). After the fall of the communist regimes in 1989, most of the limits were eased and the number of university students in the former state-socialist countries began to rise; the Bologna declaration started the massive educational expansion in these countries, together with the countries of Western Europe.

5 This classification comes from the 1997 version of the ISCED, i.e. before the Bologna declaration. A new version, the ISCED 2011, makes a distinction between the levels of tertiary education (bachelor's - ISCED 6, master's - ISCED 7, PhD - ISCED 8); however, this classification only became relevant to empirical research after 2014.

${ }_{6}$ The analysed countries are (abbreviations in parentheses): Austria (AT), Belgium (BE), Bulgaria (BG), Croatia (HR), Cyprus (CY), Czech Republic (CZ), Denmark (DK), Estonia (EE), Finland (FI), France (FR), Germany (DE), Greece (GR), Hungary (HU), Iceland (IS), Ireland (IE), Italy (IT), Latvia (LV), Lithuania (LT), Luxembourg (LU), Netherlands (NL), Norway (NO), Poland (PL), Portugal (PT), Romania (RO), Slovakia (SK), Slovenia (SI), Spain (ES), Sweden (SE), Switzerland (CH), and United Kingdom (UK).
} 
Figure 1. Educational expansion in 30 European countries between 2003 and 2015 (\%)

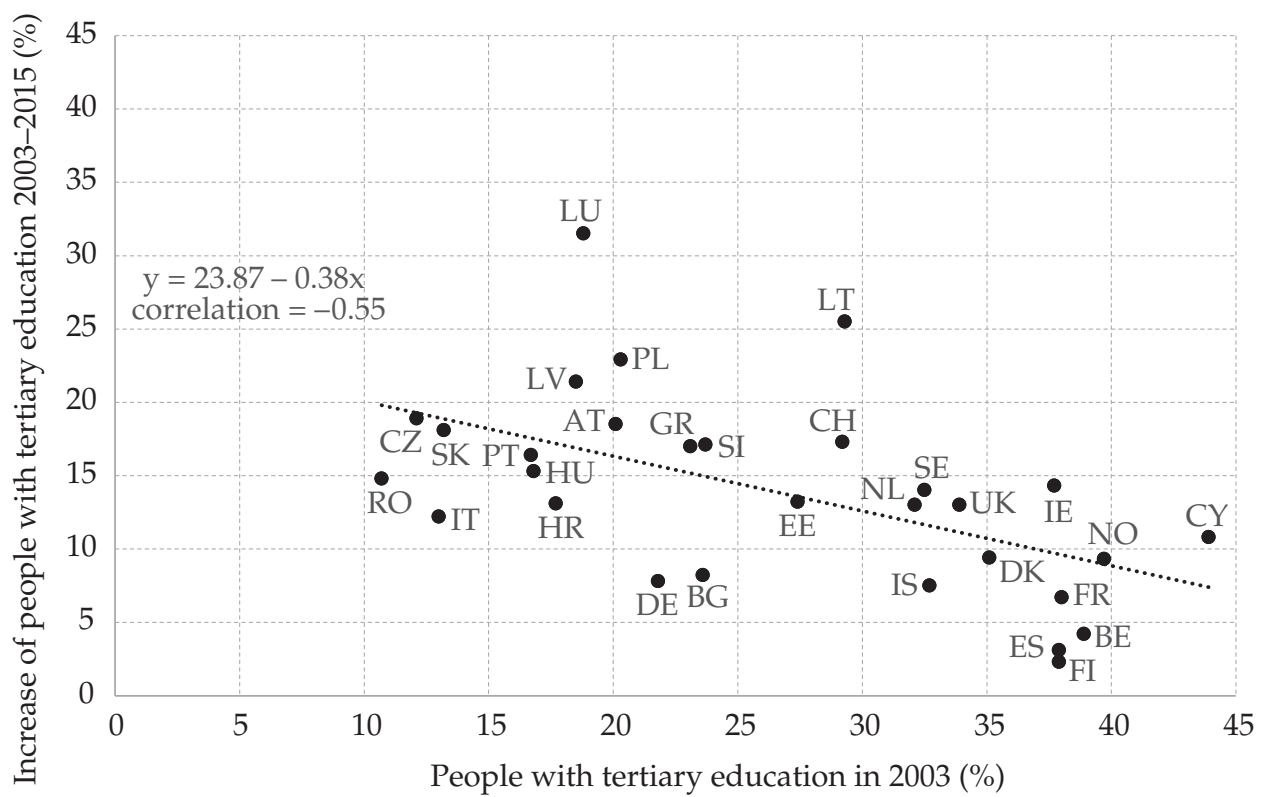

Source: OECD (2019), Population with tertiary education (indicator).

Note: Tertiary education indicated by ISCED 2011 (5-8 levels) for age group 25-34.

pean Union average, Luxembourg and Greece reached parity with the EU average by 2015 (Luxembourg 18.8\% + 31.5\%, Greece 23.1\% + 17\%). Among the former socialist countries, which were below average in 2003 , Poland $(20.3 \%+22.9 \%)$, Slovenia $(23.7 \%+17.1 \%)$, and Latvia $(18.5 \%+21.4 \%)$ reached the EU average. The other former socialist countries did not reach the EU average by 2015, despite intense expansion. The situation was similar in four Western European countries: Austria $(20.1 \%+18.5 \%)$, Portugal $(16.7 \%+16.4 \%)$, Germany $(21.8 \%+7.7 \%)$, and Italy $(13.0 \%+13.2 \%)$. These countries were still below the EU average in 2015 .

Martin Trow [1973] makes a distinction between three types of massification of higher education, which differ in their social functions and goals: elite, mass, and universal. The transition between the elite and mass phases takes place when more than $15 \%$ of a birth cohort enters the given educational phase. The mass system becomes universal when at least $50 \%$ of a birth cohort enters higher education. ${ }^{7}$ In terms of the goals, tertiary education is supposed to move from

7 The massification of the tertiary level is associated with progressive secularisation and the simultaneous dismantling of social elites [Trow 1973]. 
building narrow elites (in the elite phase), through the training for new and demanding types of occupations (in the mass phase), to increasing the adaptability of wide strata of the population to conditions that are constantly changing (in the universal phase).

From the perspective of this typology, no country in this analysis can be described as elite. The lowest proportions of the population as students in higher education in 2015 were found in Italy (25.2\%), Romania (25.5\%), and Germany (29.6\%). The group of universal countries, where the proportion of higher education students in the 25-34 age group is higher than 50\%, comprised four countries: Lithuania (54.8\%), Cyprus (54.7\%), Ireland (52\%), and Luxembourg (50.3\%).

Previous research concerned with the changing role of education in the labour market [cf. Ultee 1980; Olneck and Kim 1989; Bol 2015; Bukodi and Goldthorpe 2016; Rotman, Shavit and Shalev 2016; Fujihara and Ischida 2016] did not take into account the fields of study. People with different fields of study have been seen as competing for the same positions in the labour market. It was supposed that they stand in one labour queue [Thurow 1975]. However, if we assume that graduates of different study fields compete for different jobs, as recently suggested by Ortiz and Rodriguez-Menés [2016], we also have to assume that they stand in different labour queues. In his typology of educational expansion, Trow [1973] assumed that gradual massification also means a differentiation among schools. Tertiary education, which was originally offered by a limited number of elite universities, strictly separated from the influences of the labour market, is, in a time of educational expansion, also obtained at institutions of higher education that are not of the university type. These institutions do not share the academic values of elite universities, and often they focus primarily on developing skills that can be used in the labour market. The consequence is that there are differences among study fields; these differences are not affected by the expansion to the same extent. According to Thurow [1975], there is a job queue in the labour market wherein job applicants distinguish among types of jobs, ranking the jobs according to their technical complexity. Engineers with technical training apply for jobs that are different from those sought by dentists with medical training or journalists and sociologists with education in the humanities. Heckman et al. [2006] confirm this when they show that the benefits of education in American society are contingent primarily upon the chosen field. According to their findings, more important than the diploma is the field of study in which the diploma has been obtained. ${ }^{8}$

\footnotetext{
${ }^{8}$ Structural changes in labour markets also speak for considering fields of study. If, for instance, the number of job opportunities in agriculture dramatically decreases due to a transition from being a primary to a secondary industry, as described by Breen [2004], it will be more difficult for graduates in agriculture to find relevant jobs (it is known that the labour markets of developed countries first shift from agricultural to industrial production, and then from industrial production to social services).
} 
When considering the occupational returns to education in a time of educational expansion, it is therefore necessary to consider not only the level of education (empirically measured in absolute and relative terms), but also the field of study. Following this argument, we expect that educational expansion changes both the relationship between level of education and occupation and the relationship between study field and occupation. If this occurs, then the identification of the study fields that gain a relative advantage in the labour market compared to other study fields during an educational expansion should contribute to the interpretation of the increase in educational positionality, as we assume in hypothesis 2 .

\section{Data and variables}

We analyse data from the European Union Labour Force Survey (EU-LFS) from 2014, 2015, and 2016 [EU Labour Force Survey... 2017]. ${ }^{9}$ The data come from 30 European countries (Figure 1). Because we are interested in the school-work connection, which is conceptualised as a non-monetary benefit of education [Vila 2000], we limit our analysis to the 25-34 age group. These are the individuals who have already left the education system and are working. Within this group, we distinguish 12 graduated cohorts (defined by the year in which they left school). The first cohort graduated in 2003, the second in 2004, and so on, until the final cohort of 2014. The total number of respondents analysed is 991922 (Table A1 in the Appendix shows the number of respondents analysed for each country and year).

The dependent variable is current occupation, indicated in the data as ISCO08 (International Standard Classification of Occupations) [cf. ILO 2008]. From this variable, we constructed the International Socio-economic Index of Occupational Status (ISEI) [Ganzeboom, De Graff and Treiman 1992; Ganzeboom and Treiman 1996, 2003]. The 'philosophy' of the ISEI is that occupation transforms education into income. The ISEI is a continuous scale in which the higher the value, the higher the socio-economic position in the labour market. The ISEI is typically constructed from a 4-digit ISCO, which, however, is not present in the EU-LFS data. A 3-digit ISCO is available instead. We multiplied it by 10, thereby extending it to a 4-digit ISCO. It is possible to perform this operation because ISCO is hierarchically collapsible [ILO 2008]..$^{10}$

\footnotetext{
9 The EU-LFS is a survey carried out by European Union member states and is harmonised by Eurostat so that the results are comparable across countries and time periods. The sample represents all people living in households who are over the age of 15 at the time of the survey. The respondents living in 'institutional households', i.e. army barracks, hospitals, or prisons, are not included. For instance, in the year 2016, data on 1.5 million respondents were available from 28 European Union members plus Iceland, Norway, and Switzerland.

${ }^{10}$ For instance, transforming the four-digit ISCO code 2211 to 221 means alternation from the group 'general practitioners' to the more general group, 'medical doctors'. A compari-
} 
Education is indicated by ISCED11 categories $(0,100,200 \ldots 800) .{ }^{11}$ We transformed these categories into an interval variable of years in the education system: $12,14,16,18$, and 20 years (for this transformation, see the Appendix, Table A2). In this way we operationalise education in absolute terms that remain unadjusted across graduated cohorts and countries. As our goal is to compare the effects of absolute and relative educations, we created standardised values for this variable-z-scores (mean $=0, S D=1$ ) -and work with them.

We indicate the relative education with a proportion measure (percentile scores of education from 0 to 100) for cohorts and countries. A number of previous studies dealing with the relative concept of education have used the same indicator [cf. Ultee 1980; Olneck and Kim 1989; Bol 2015; Ortiz and Rodriguez-Menés 2016]. When constructing the percentile scores for education, we first connected the ISCED11 categories with years spent in the education system (see the Appendix, Table A2, for this transformation) and then converted these into a ranked variable. In this way, we determined the position of each respondent relative to others in the graduated cohort and country. These positions are influenced by the number of years in the education system of other respondents, i.e. by the composition of each graduated cohort. To analyse relative education, we also created standardised values for this variable ( $\mathrm{z}$-scores, mean $=0, \mathrm{SD}=1$ ) and work with them.

Studies that have posed similar questions in the past have assumed that the effect of educational expansion is not horizontally (by study fields) differentiated [cf. Ultee 1980; Bol 2015], with one exception [cf. Ortiz and Rodriguez-Menés 2016]. In our analysis, we reject the assumption of one-dimensionality, and we explicitly control the results for the fields of study. In the data, the different fields of educational attainment are indicated by the ISCED97 and ISCED11 codes. We have recoded these into six categories: (1) unspecified and general; (2) education, social, and services; (3) natural, computers, and IT; (4) engineering, construction; (5) agriculture, forestry, and veterinary; (6) health and welfare (for more on this, see the Appendix, Table A2).

Other variables for which we control the effect of absolute and relative education on occupation are gender, family status, and full-time/part-time job. We consider the effect of these three variables because it is known that the occupa-

son of ISEI as calculated from a 4-digit ISCO with the ISEI calculated from a 3-digit ISCO shows that the average deviation caused by using a 3-digit ISCO is 2.05 ISEI scores. The errors for individual ISCO codes range from 0 to 21.96 ISEI scores, with more than half of the codes showing an error of less than 1 ISEI score.

${ }^{11}$ The International Standard Classification of Education (ISCED) is indicated according to the ISCED97 standard in the EU-LFS data until 2013, which does not make it possible to distinguish between levels of tertiary education (BA, MA). After 2014, the ISCED11 is incorporated in the data, and it is possible to distinguish between graduates of secondary education, as well as BA, MA, and doctoral programmes of tertiary education. Since the ISCED97 and the ISCED11 categories are not unambiguously transformable, we analysed only data from 2014, 2015, and 2016. 
Table 1. Descriptive statistics

\begin{tabular}{|c|c|c|c|c|c|}
\hline Variable & Mean & $\begin{array}{l}\text { Std. } \\
\text { Dev. }\end{array}$ & Min. & Max. & Categories \\
\hline \multicolumn{6}{|l|}{ Individual variables } \\
\hline ISEI & 49.40 & 21.28 & 11.01 & 88.70 & \\
\hline $\begin{array}{l}\text { Education in years } \\
\text { (standardised) }\end{array}$ & 0.00 & 1.00 & -1.07 & 2.16 & \\
\hline $\begin{array}{l}\text { Education in } \\
\text { percentiles } \\
\text { (standardised) }\end{array}$ & 0.00 & 1.00 & -1.25 & 2.10 & \\
\hline Study fields & 2.92 & 1.48 & 1 & 6 & $\begin{array}{l}\text { 1-unspecified/general; } \\
\text { 2-education/social/services; } \\
\text { 3-natural/computer/IT; } \\
\text { 4-engineering/construction; } \\
\text { 5-agriculture/forestry/vet- } \\
\text { erinary; 6-health/welfare }\end{array}$ \\
\hline Gender & 1.50 & 0.50 & 1 & 2 & 1-man; 2-woman \\
\hline Marriage & 1.31 & 0.46 & 1 & 2 & 1-other; 2-married \\
\hline Full-time job & 1.84 & 0.36 & 1 & 2 & $\begin{array}{l}\text { 1-part-time } \\
\text { 2-full-time job }\end{array}$ \\
\hline \multicolumn{6}{|l|}{ Contextual level } \\
\hline Country by cohort & - & - & 1 & 360 & \\
\hline \multicolumn{6}{|l|}{ Contextual variable } \\
\hline $\begin{array}{l}\text { Educational } \\
\text { expansion by } \\
\text { countries and } \\
\text { cohorts }\end{array}$ & 31.62 & 10.21 & 10.70 & 54.00 & $\begin{array}{l}360 \text { numbers for } 12 \text { cohorts } \\
\text { in } 30 \text { countries }\end{array}$ \\
\hline
\end{tabular}

Source: Labour Force Survey (LFS) from years 2014, 2015 and 2016; the contextual variable comes from the OECD [2019].

Note: There were 991922 respondents.

tional returns to education are different for men and women [Manning and Saidi 2010; Peet, Fink and Fawzi 2015], for single and married people [DiPrete and Buchman 2006; Hout 2012], and in the case of full- and part-time job positions [Bol 2015].

The dataset is characterised by a hierarchical structure: at the first (micro) level, individuals are settled. These individuals are nested in the cohorts that constitute the second (macro) level of analysis. The cohorts are nested in the countries that constitute the third (macro) level of analysis. Because of this structure, multilevel modelling is employed to estimate the effect of the predictors on ISEI 
(for details on this method, see Gelman and Hill [2006] and Rabe-Hesketh and Skrondal [2012]). The major advantage of multilevel models is their ability to combine characteristics from the micro level with those from the macro levels, assuming that the variation in the dependent variable comprises two parts, withinand between-group components.

At the contextual levels, we are interested in the effect of educational expansion on the effect of education on occupation. Educational expansion is a macro variable. The effect of this variable should therefore be qualitatively different from the effects of individual variables. We operationalised educational expansion as the proportion of people with tertiary education (indicated by ISCED11, 5-8 levels) aged 25-34 in each country and cohort (together, 360 numbers given by 12 cohorts in 30 countries). This variable defines our 360 analytical macro contexts and allows us to turn the 3-level hierarchical structure of the data (individuals in cohorts and cohorts in countries) into a 2-level hierarchical structure (individuals in cohorts by countries). With this transformation we lose one level in the data, but we increase the number of contexts in the second level. The estimation of the effect of educational expansion should then be more reliable [cf. Bryan and Jenkins 2016]. Table 1 presents the descriptive statistics of all the variables (a detailed description is available in Table A2 in the Appendix).

\section{Methods and statistical analysis}

In order to identify the trends in the effect of education on occupation and test our hypotheses, we estimated two sets of models. The first set includes five twolevel random effect models for absolute education. The second set includes five two-level random effect models for relative education. The models are identical; they differ only in the standardised variable of education. The general equation for these models is:

$$
y_{i c}=X_{i c} \beta+Z_{c} \gamma+\mu_{c}+e_{i c}
$$

where $y_{i c}$ is the ISEI score for each respondent $i$ and context $c ; X_{i c}$ are observed individual variables with estimated parameters $\beta$; and $Z_{c}$ is observed contextual variable of educational expansion (that does not vary on an individual level) with estimated parameter $\gamma$. The unobserved individual effect is $e_{i c}$ and the contextual effect $u_{c}$ (both assumed to be normally distributed and uncorrelated with the observed individual and contextual variables). We start with the null random intercept model (in which no covariates are taken into account) and continue by adding relevant covariates and adding random-slope models for education with and without a cross-level interaction term.

The estimated models are reported in Table 2 for absolute education and in Table 3 for relative education. The interclass coefficient (ICC) in Model 0 reveals 
Sociologický časopis/Czech Sociological Review, 2019, Vol. 55, No. 6

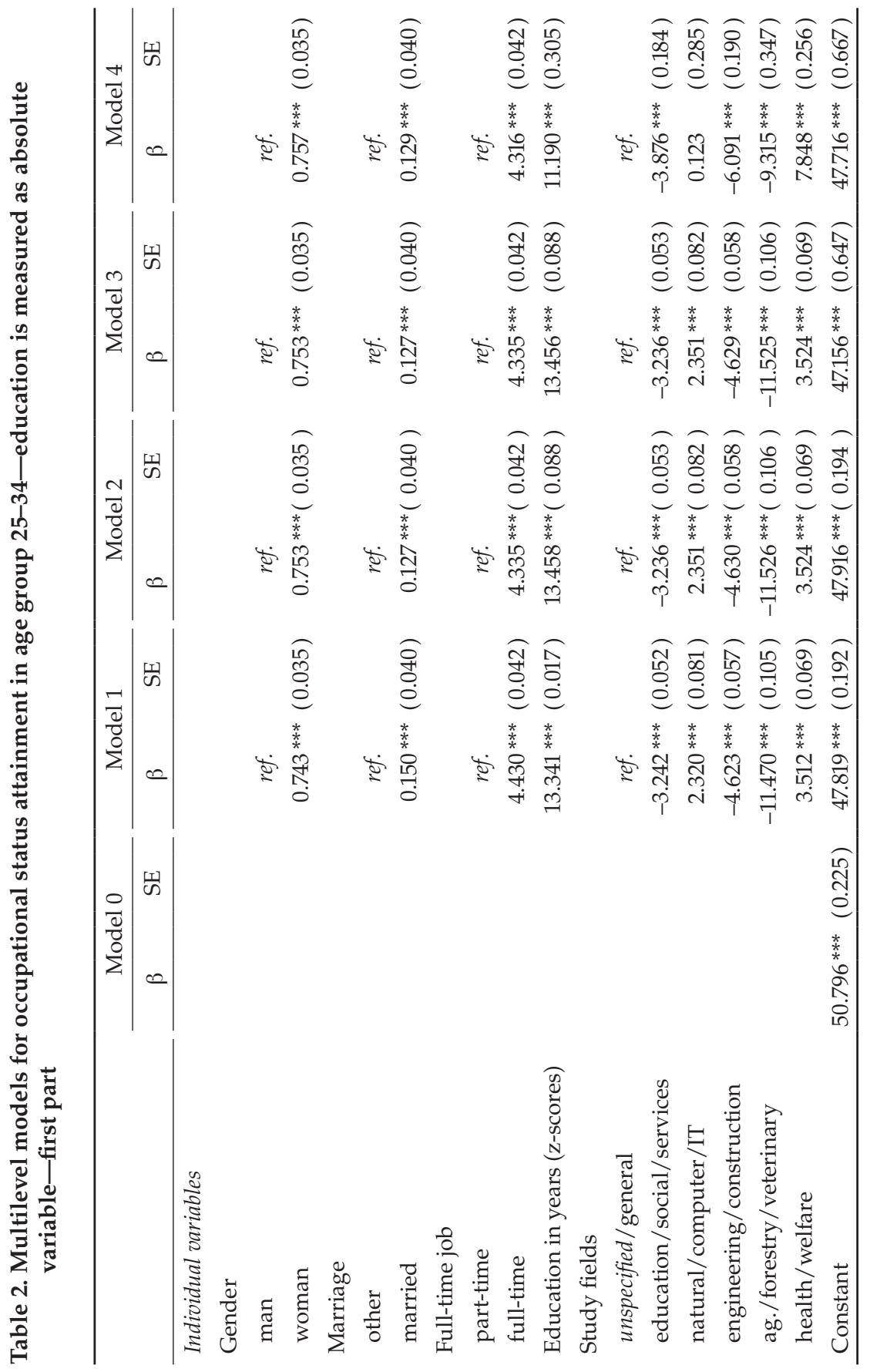


Articles

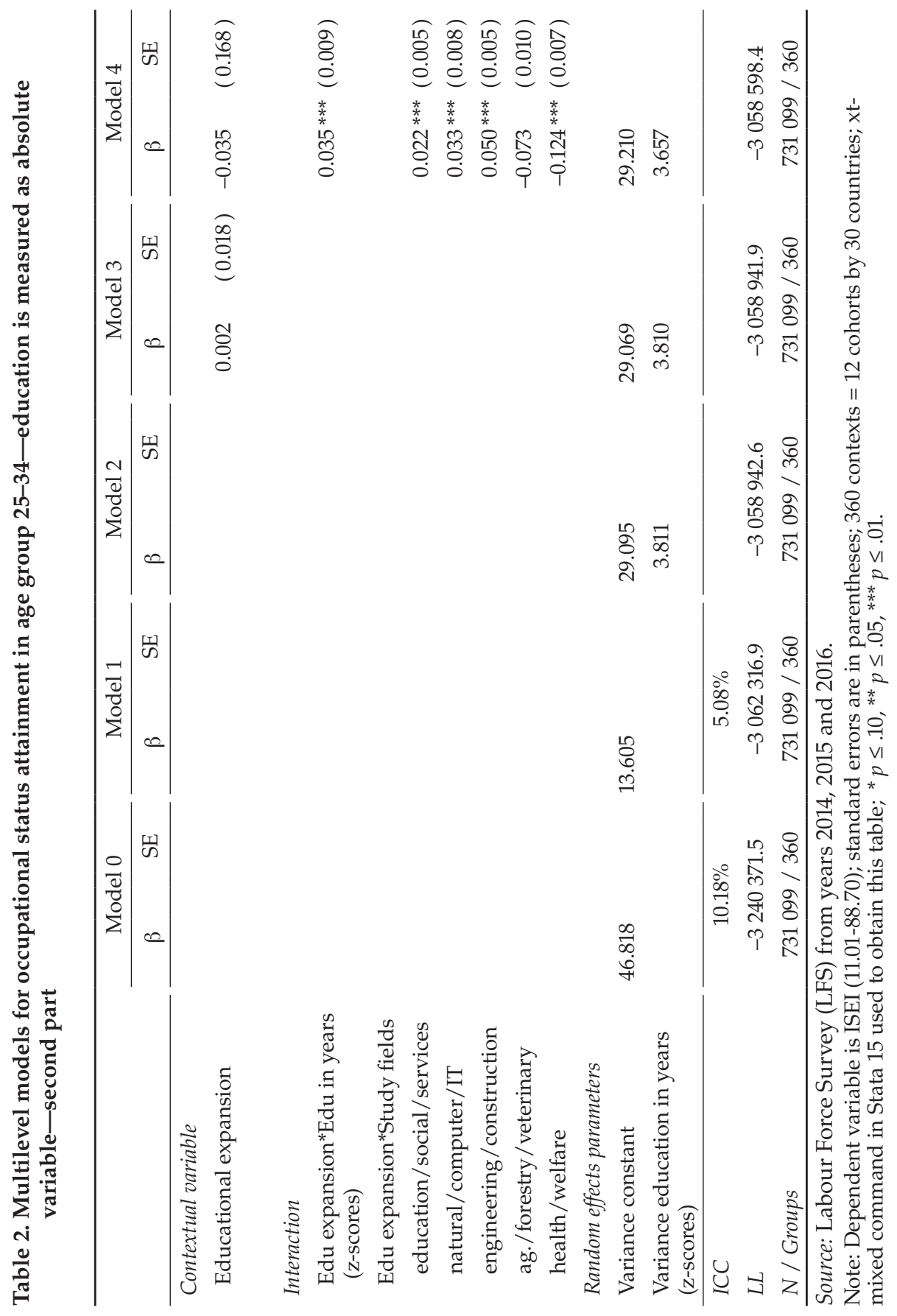




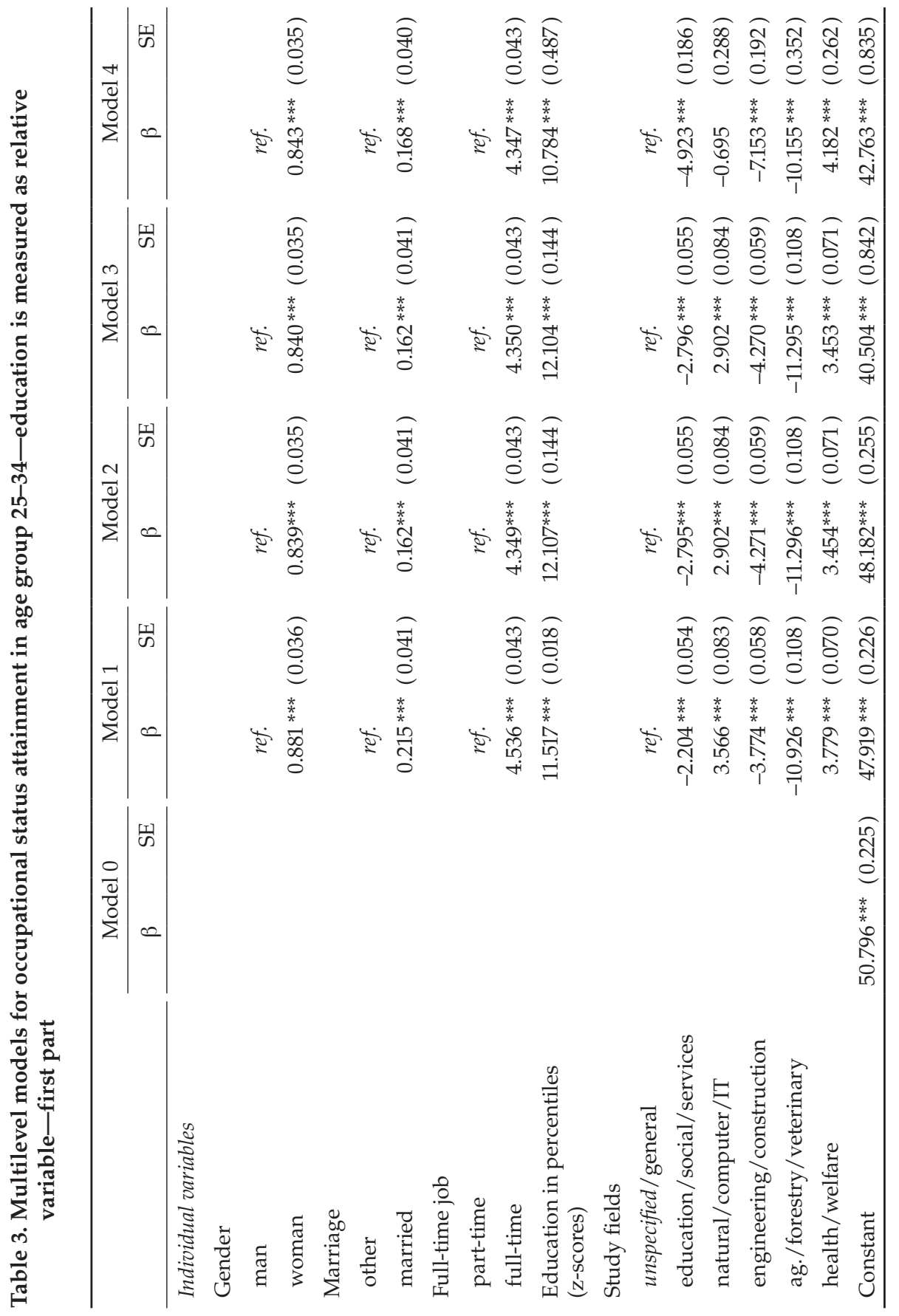


Articles

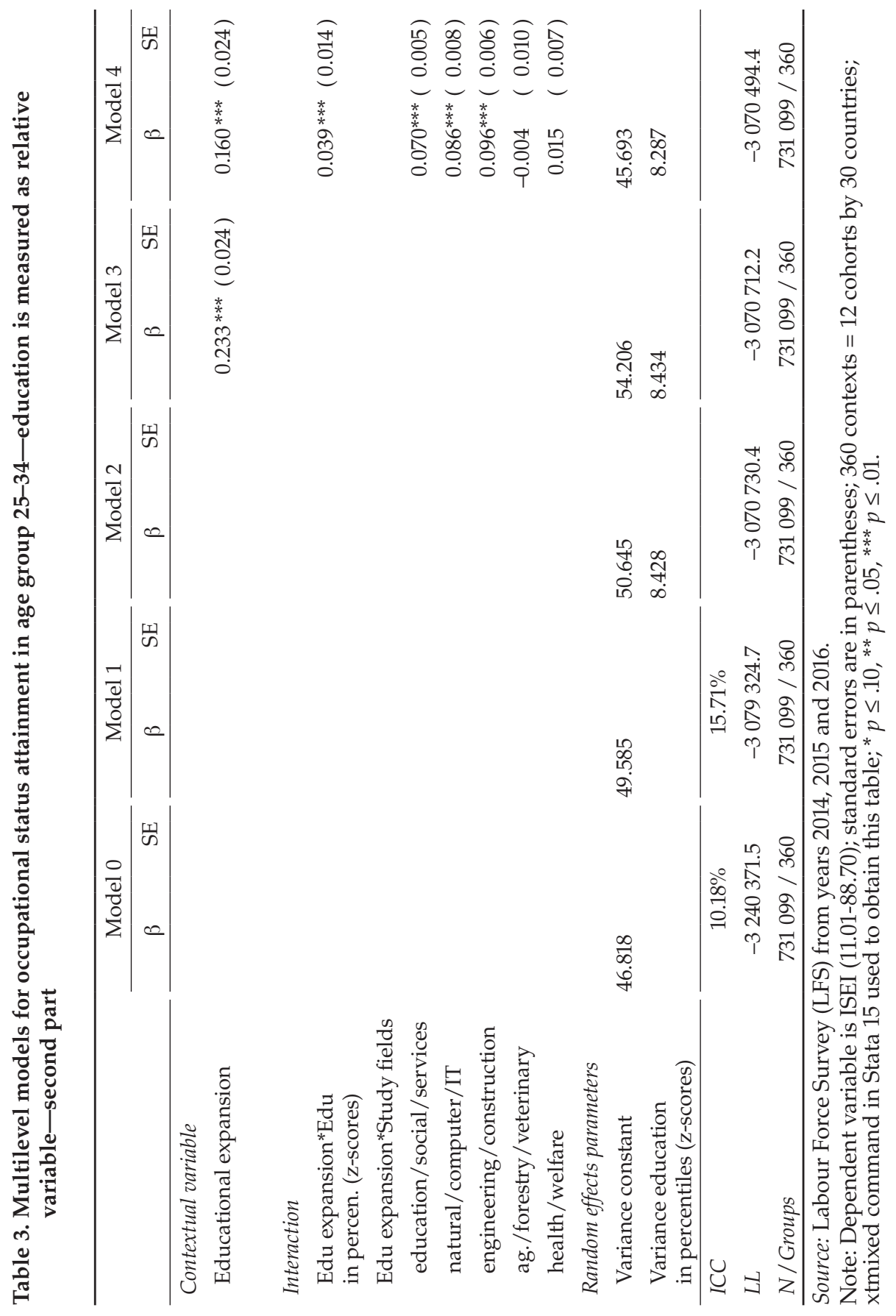


the degree of variance in the dependent variable (ISEI) that is attributable to the context level. While the model has no explanatory variables, it suggests that occupation status is likely shaped by variation at the individual level (not much variance in the ISEI stems from the context level: $10.18 \%$ ).

When individual-level factors are added to the null model (Model 1 in Table 2 and Table 3), we see a decrease in ICC for absolute education, but an increase in ICC for relative education. ${ }^{12}$ This confirms that ISEI is mostly determined by micro-level factors (at the individual level). We can also see a considerable improvement in the LL statistic, meaning that these variables markedly increase the model fit. We evaluated the significance of the change by using a likelihood-ratio test, the value of which can easily be derived from the difference in the LL criteria of the compared models.

All the individual-level variables are statistically significant. ${ }^{13}$ Compared to men, women have a slightly higher average ISEI (by 0.74 in absolute education, by 0.88 in relative education). Similarly, those who are married have a slightly higher average ISEI than others (by 0.15 in absolute education, by 0.22 in relative education). A distinctly higher average ISEI can be found in the comparison of full-time jobs with part-time jobs (by 4.43 in absolute education, by 4.54 in relative education). Both variables on education are standardised (z-scores), and they increase the average ISEI. Specifically: if absolute education increases by $1 \mathrm{SD}$, the average ISEI increases by 13.34. If relative education increases by $1 \mathrm{SD}$, the average ISEI increases by 11.52 .

In Model 1, absolute education, natural/computer/IT, and health/welfare fields increase the average ISEI when compared to unspecified/general fields (by 2.32 and 3.51, respectively). The other fields decrease the average ISEI when compared to the reference category (the strongest negative effect is in the agriculture/ forestry/veterinary field). The same conclusions apply also for Model 1 with relative education; only the effects are slightly different. The effects of all individual variables remain almost identical across the other more complex models (Models 2 to 4 ) for absolute as well as relative education. We therefore consider them to be robust across the models.

Model 1 for both absolute and relative education assumes a fixed effect for education. But because it cannot be ruled out that this variable influences ISEI differently by countries and cohorts [cf. Shavit and Müller 1998], in the next step

\footnotetext{
12 An increase in the ICC happens in cases where 'the estimated level-1 variance decreases more than the level-2 variance does when covariates are added' [Rabe-Hesketh and Skrondal 2012: 137].

${ }^{13}$ In the models, we report significance because we understand it within the multilevel models as 'model-based'. In this case, the statistical model can be understood as a 'datagenerating mechanism', and the randomness of the parameters results from the distribution of responses and not from the sampling units of a finite population (for more on this, cf. Rabe-Hesketh and Skrondal [2012]).
} 
we allowed the slope for the education variable to vary randomly across contexts. As reported for Model 2 in Tables 2 and 3, we found that the effect is random. In the case of absolute education, the fixed effect is 13.46 and its random effect is 3.81. In the case of relative education, the fixed effect of education is 12.11 and the random effect is 8.43..$^{14}$ This corresponds with the findings of Shavit and Müller [1998], who showed that the association between education and occupation is influenced by the institutional context. They talk about the stratification and standardisation of education systems, the occupational specificity of vocational education, and the relative size of the tertiary sector. Countries that differ in these characteristics also differ in the effect of education on occupation [cf. Shavit and Müller 1998]. The variance in relative education in Model 2 is significantly higher than in absolute education. This indicates that relative education reacts to changes due to educational expansions more sensitively than absolute education. The downside of using the random effect model is that it is not possible to calculate the interclass correlation [c.f. Kreft and De Leeuw 1998]. This is too minor a downside to require considering a better specified model.

In Model 3 in Tables 2 and 3, we added a context-level variable to the previous model: educational expansion. This variable would play a role in the relationship between education and occupational achievement. Its effect is significant only for relative education. Moreover, in the first case it is zero; in the second case it is positive. This means that in absolute education, educational expansion does not have an effect on average ISEI; in relative education, it works in favour of higher average ISEI. Furthermore, while the LL criterion improved after including the context-level variable, the change is rather small compared to the shift in this criterion from Model 0 to Model 1. This again confirms that ISEI is mostly determined by micro-level variables.

Model 4 (in Tables 2 and 3) includes cross-level interactions that express the joint effect of education and educational expansion and the joint effect of study fields and educational expansion. Hypotheses 1 and 2 predicted that educational expansion should influence the absolute and the relative effects of education on occupation in different ways. Educational expansion does not change the effect of absolute education, while it strengthens the effect of relative education. Figure 2 shows the effects of absolute and relative education on ISEI (y-axis) in relation to the rate of educational expansion (x-axis). These are the margins from Model 4, presented in Tables 2 and 3. Educational expansion does not change the effect of absolute education on ISEI; it strengthened the effect of relative education. When the proportion of people with tertiary education (aged $25-34$ ) is low $(10 \%)$, the effect of absolute education is a little bit stronger than the effect of relative education. When the proportion of educated people is $50 \%$, relative education is the stronger determinant of occupation. Both variables are standardised (z-scores),

${ }^{14}$ It can be assumed that the effect of education is normally distributed around the fixed effect. This means that $95 \%$ of its values lie in the range of $\pm 2 \sigma$ around the mean. 
Figure 2. Model effects of absolute and relative education by educational expansion (Model 4 estimation)
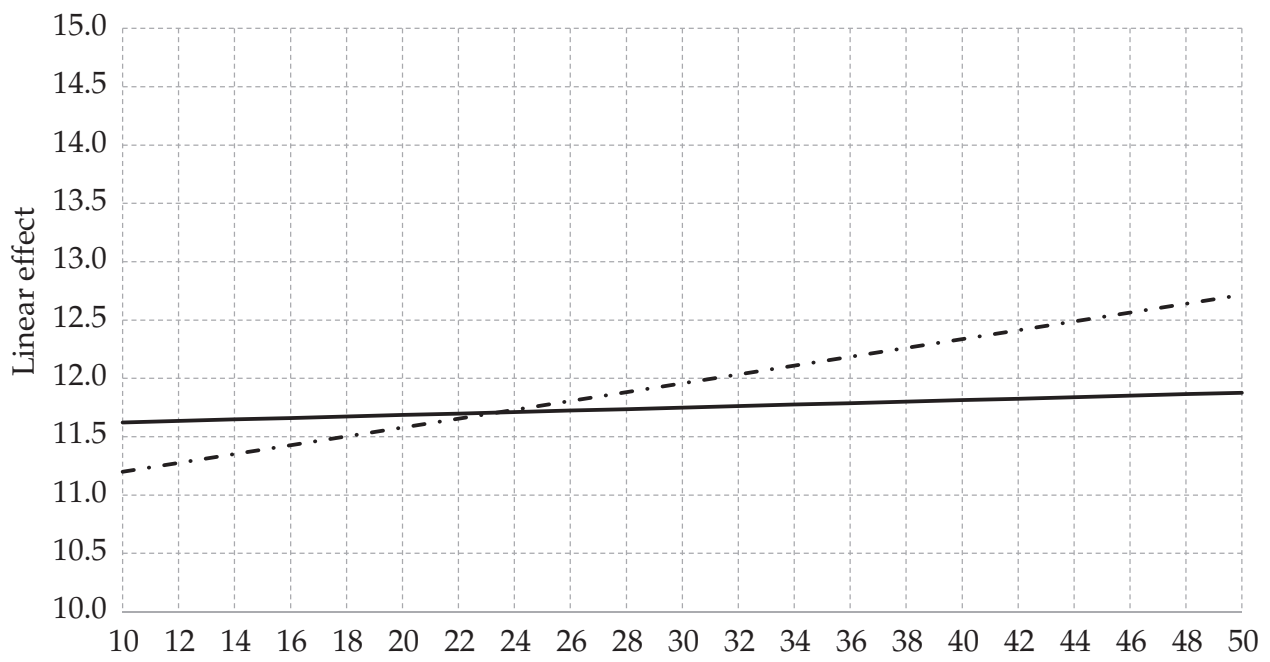

People with tertiary education at age 25-34 (\%)

_ absolute education _. - relative education

Note: The absolute education effect is estimated from Model 4 in Table 2, relative education effect is estimated from Model 4 in Table 3.

and their effects are therefore comparable to each other. Based on Model 4, we do not reject hypotheses 1 and 2, and conclude: education changes its role in the labour market from absolute to relative as a result of educational expansion.

Why did this happen? Figures 3 and 4 show the average ISEI (y-axis) by study field in relation to educational expansion with regard to absolute and relative education (respectively). These are again margins from Model 4, presented in Tables 2 and 3. In both cases, study fields differentiate positions in the labour market. At the beginning of the expansion ( $10 \%$ of people with tertiary education), the effect of study field on ISEI for absolute education was significantly higher than the effect of study field for relative education. For instance, in the absolute model agriculture/forestry/veterinary is about 42 ISEI scores; in the relative model, it is about 32 ISEI scores. Educational expansion decreases the average ISEI in agriculture/forestry/veterinary and health/welfare fields in the absolute model. In the relative model, the effect of study fields strengthens. The fields that rose the most in the relative model are natural/computer/IT and engineering/construction. Agriculture/forestry/veterinary strengthened only a little bit. The distances between the effects of other fields remain constant. 
Figure 3. Model effects of study fields by educational expansion (absolute education, Model 4 estimation)

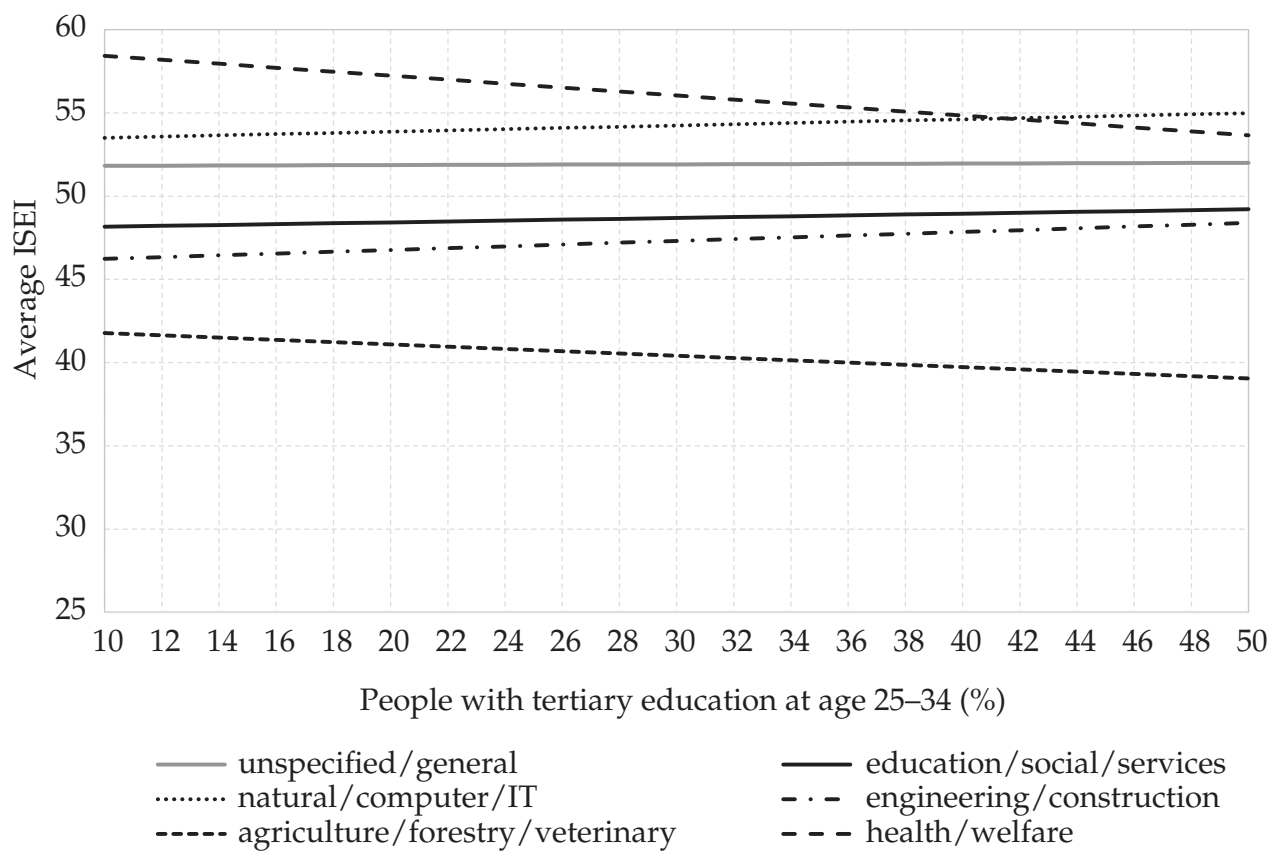

Note: The study field effect is estimated from Model 4 in Table 2.

These findings suggest that the shift in education should be interpreted as a shift into a positional good during educational expansion as a consequence of the deployment of new technologies in production, computerisation, and robotisation in the labour market. Such changes increase the demand for employees in the computing and IT fields and give individuals with education in these fields a relative advantage over those who study other fields. This is probably a period effect that would correspond to the skill-biased technological change theory [Bernardi and Ballarino 2016]. According to this theory, people at the other end of the spectrum of the educational structure should be at a disadvantage when compared to other fields. However, this was not observed in our data. In Figure 4 , we see this with the category 'unspecified/general'; the effect of this field on occupation was rather strong at the beginning of the expansion, and educational expansion made it even stronger. Therefore, Goos, Manning and Salomons [2014] speak of a task-biased technological change theory. According to this theory, the positionality of education is not in some advanced skills; the occupational returns depends on the tasks an employee can carry out as a result of those skills and how routine these tasks are. 
Figure 4. Model effects of study fields by educational expansion (relative education, Model 4 estimation)

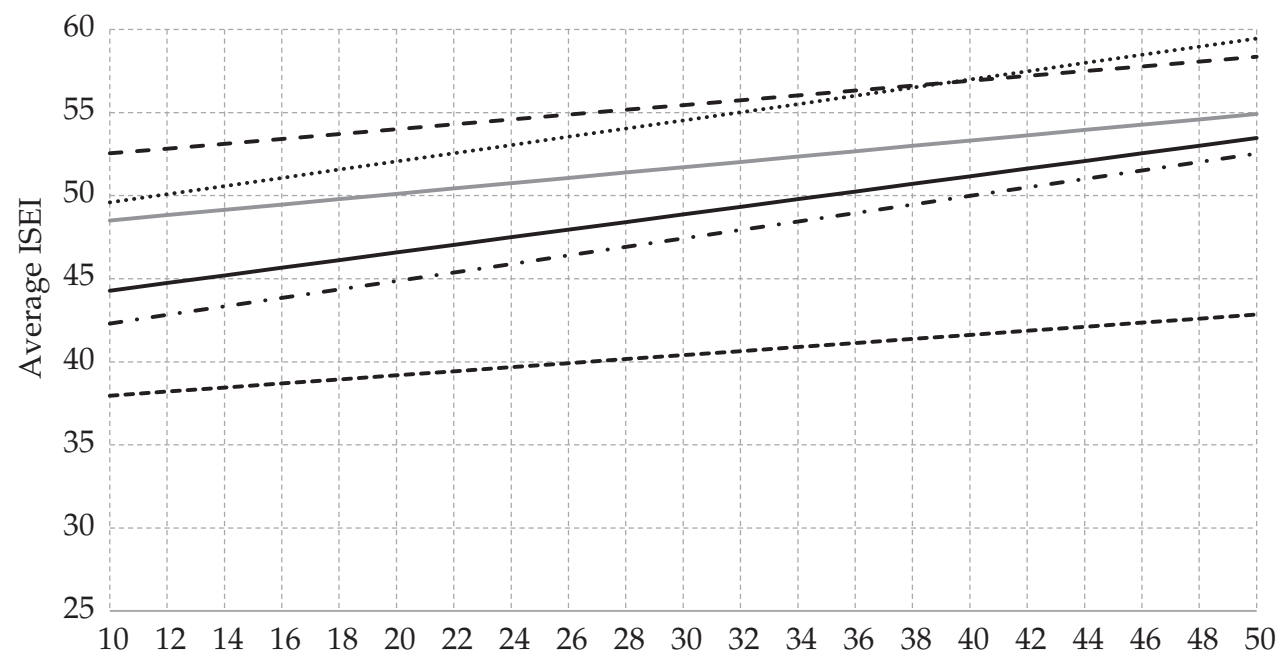

People with tertiary education at age 25-34 (\%)

- unspecified/general

........ natural/computer/IT

----- agriculture/forestry/veterinary
— education/social/services

- - engineering/construction

- - - health/welfare

Note: The study field effect is estimated from Model 4 in Table 3.

\section{Conclusion}

A number of sociological analyses [cf. Ross and Wu 1995; Pallas 2006; Hout 2012] show that more highly educated people tend to be healthier, have a longer life expectancy, and experience better well-being. They see their occupation as a form of self-fulfilment, not as a routine activity necessary to obtain financial resources for living. They differ in patterns of assortative mating and in the level of educational homogamy; their political votes are relatively stable, without swings to extremist political parties; and subjectively these people are also happier than people with lower education.

We explored the relationship between education and occupation during a period of educational expansion in 30 European countries. In the introduction, we posed a question: how does educational expansion influence the effect of education on occupation? We conceptualised education as an individual variable in absolute as well as in relative terms (as a nominal and positional good). We started with the assumption that occupational returns to education are not absolute, 
as was long expected in the social sciences, but rather that they are contingent upon time and place. We therefore expected that they change according to social context. In contrast to previous studies focused on similar topics, we additionally included the effect of study fields in the analysis. The identification of this effect means the education-occupation relationship is multidimensional and it also contributes to the interpretation of the findings.

We suggest interpreting the change from absolute education to relative education on the basis of study fields using the task-biased technological change theory. According to the original skill-biased technological change theory, those in possession of university diplomas are rewarded by the labour market for their higher qualification, which enables them to take advantage of the quickly evolving sophisticated technologies. People with lower education should be pushed out of the labour market, and their work should be taken over by machines or employees in countries with lower labour costs [Bernardi and Ballarino 2016]. However, the empirical findings contradict this theory. They show that the occupational returns to education also increase at the lowest end of the educational spectrum during educational expansion. Lower-educated employees are able to obtain well-paid work in the developing services sector in jobs that cannot be outsourced to other countries. In contrast, a number of relatively qualified workers with routine tasks lose jobs as a result of computers taking over their tasks. In this respect, Goos, Manning and Salomons [2014] formulated the task-biased technological change theory. According to this theory, the tasks are more important than the skills, and the distinguishing criterion of the occupational return to education is the level of routine [c.f. Autor, Levy and Murnane 2003; Manning 2004; Oesch and Rodriguez Menés 2010]. Employees with more routine jobs are more easily replaceable by computers even if they have a relatively high education level. In our data, this specifically means that the effect of the computer and IT study field on occupation grew stronger, the health and welfare study field weakened, and the effect of the general and unspecified study field did not weaken.

The positional change of education should be understood as a period effect. In times of technological decline or economic crisis, these changes would probably be different. It is possible that under different economic circumstances educational expansion could lead to a decline in the labour-market value of tertiary diplomas as described by the theory of inflation [Berg 1970; Collins 1979; Bourdieu and Passeron 1990]. It is also possible that the role of education would shift in a way not yet described by social sciences. All of this leads to the conclusion that the merit of education with respect to one's labour market performance should not be seen as fixed but rather as context-dependent. 
TOMÁš KATRŇÁK is a professor at the Faculty of Social Studies of Masaryk University in Brno. His areas of expertise include social stratification, social statistics, and methods of sociological data analysis.

TOMÁš DosedĚL is a researcher at the Faculty of Social Studies of Masaryk University in Brno. His areas of expertise include social stratification, educational expansion, and technological change.

\section{References}

Aamodt, P. O. and C. A. Arnesen. 1995. 'The Relationship Between Expansion in Higher Education and the Labour Market in Norway.' European Journal of Education 30 (1): 65-76, https:// doi.org/10.2307/1503568.

Ábrahám, Á. 2008. 'Earnings Inequality and Skill-Biased Technological Change with Endogenous Choice of Education.' Journal of the European Economic Association 6 (2-3): 695-704, https://doi.org/10.1162/JEEA.2008.6.2-3.695.

Acemoglu, D. 2002. 'Technical Change, Inequality, and the Labor Market.' Journal of Economic Literature 40 (1): 7-72, https://doi.org/10.1257/jel.40.1.7.

Arrow, K. J. 1973. 'Higher Education as a Filter.' Journal of Public Economics 2 (3): 193-216, https:// doi.org/10.1016/0047-2727(73)90013-3.

Autor, D. H., F. Levy and R. J. Murnane. 2003. 'The Skill Content of Recent Technological Change: An Empirical Exploration.' The Quarterly Journal of Economics 118 (4): 1279-1333, https:// doi.org/10.1162/003355303322552801.

Barone, C. and H. G. Van de Werfhorst. 2011. 'Education, Cognitive Skills and Earnings in Comparative Perspective.' International Sociology 26 (4): 483-502, https://doi.org/10.1177/0268580910393045.

Beck, U. 2011. Riziková společnost: na cestě k jiné moderně. (The risk society: on the road to a different modernity) Prague: Sociologické nakladatelství.

Becker, G. S. 1935. 'Human Capital, Effort, and the Sexual Division of Labor.' Journal of Labor Economics 3 (1) Part 2: S33-S58.

Becker, G. 1964. Human Capital: A Theoretical and Empirical Analysis. With Special Reference to Education. Chicago, IL: University of Chicago Press, https://doi.org/10.1086/298075.

Berg, I. 1970. Education for Jobs; The Great Training Robbery. Boston, MA: Beacon Press.

Berman, E., R. Somanathan and H. W. Tan. 2005. Is Skill-biased Technological Change Here Yet? Evidence from Indian Manufacturing in the 1990. Washington, DC: The World Bank, https:// doi.org/10.1596/1813-9450-3761.

Bernardi, F. and G. Ballarino. 2016. Education, Occupation and Social Origin: A Comparative Analysis of the Transmission of Socio-economic Inequalities. Cheltenham, UK: Edward Elgar Publishing, https://doi.org/10.4337/9781785360459.

Blau, P. M. and O. D. Duncan. 1967. The American Occupational Structure. New York: John Wiley and Sons. 
Blinder, A. S. 2009. 'How Many US Jobs Might Be Offshorable?' World Economics 10 (2): 41.

Bol, T. 2015. 'Has Education Become More Positional? Educational Expansion and Labour Market Outcomes, 1985-2007.' Acta sociologica 58 (2): 105-120, https://doi.org/10.1177/0001699315570918.

Bourdieu, P. 1996. Distinction: A Social Critique of the Judgement of Taste. London: Routledge.

Bourdieu, P. and J.-C. Passeron. 1990. Reproduction in Education, Society and Culture. London: Sage Publications.

Breen, R. (ed.) 2004. Social Mobility in Europe. Oxford: Oxford University Press, https://doi.org/10.1093/0199258457.001.0001.

Brown, D. K. 2001. 'The Social Sources of Educational Credentialism: Status Cultures, Labor Markets, and Organizations.' Sociology of Education 74: 19-34, https://doi.org/10.2307/2673251.

Bryan, M. L. and S. P. Jenkins. 2016. 'Multilevel Modelling of Country Effects: A Cautionary Tale.' European Sociological Review 32 (1): 3-22, https://doi.org/10.1093/esr/jcv059.

Bukodi, E. and J. H. Goldthorpe. 2016. 'Educational Attainment-Relative or AbsoluteAs a Mediator of Intergenerational Class Mobility in Britain.' Research in Social Stratification and Mobility 43: 5-15, https://doi.org/10.1016/j.rssm.2015.01.003.

Burris, V. 1983. 'The Social and Political Consequences of Overeducation.' American Sociological Review 48 (4): 454-467, https:// doi.org/10.2307/2117714.

Card, D. and J. E. Dinardo. 2002. 'Skill-biased Technological Change and Rising Wage Inequality: Some Problems and Puzzles.' Journal of Labor Economics 20 (4): 733-783, https://doi.org/10.1086/342055.

Collins, R. 2002. 'Credential Inflation and the Future of Universities.' Pp. 23-46 in The Future of the City of Intellect: The Changing American University, edited by S. Brint. Stanford, CA: Stanford University.

Collins, R. 1979. The Credential Society: An Historical Sociology of Education and Stratification. New York: Academic Press.

Dickson, M. and C. Harmon. 2011. 'Economic Returns to Education: What We Know, What We Don't Know, and Where We Are Going-Some Brief Pointers.' Economics of Education Review 30 (6): 1118-1122, https://doi.org/10.1016/j.econedurev.2011.08.003.

Diprete, T. A. and C. Buchman. 2006. 'Gender-Specific Trends in the Value of Education and the Emerging Gender Gap in College Completion.' Demography 43: 1-24, https://doi.org/10.1353/dem.2006.0003.

Erikson, R. and J. H. Goldthorpe. 1992. The Constant Flux. A Study of Class Mobility in Industrial Societies. Oxford: Clarendon Press.

EU Labour Force Survey Database User Guide, Version: September 2017. European Commission, Eurostat 2017.

Fujihara, S. and H. Ishida. 2016. 'The Absolute and Relative Values of Education and the Inequality of Educational Opportunity: Trends in Access to Education in Postwar Japan.' Research in Social Stratification and Mobility 43: 25-37, https://doi.org/10.1016/j.rssm.2016.03.001.

Ganzeboom, H. B. G., P. M. De Graaf and D. J. Treiman. 1992. 'A Standard International Socio-economic Index of Occupational Status.' Social Science Research 21 (1): 1-56, https://doi.org/10.1016/0049-089X(92)90017-B.

Ganzeboom, H. B. G. and D. J. Treiman. 1996. 'Internationally Comparable Measures of Occupational Status for the 1988 International Standard Classification of Occupations.' Social Science Research 25 (3): 201-239, https://doi.org/10.1006/ssre.1996.0010. 
Ganzeboom, H. B. G. and D. J. Treiman. 2003. 'Three Internationally Standardised Measures for Comparative Research on Occupational Status.' Pp. 159-193 in Advances in Cross-National Comparison, edited by J. H. P Hoffmeyer-Zlotnik and C. Wolf. Boston, MA: Springer, https://doi.org/10.1007/978-1-4419-9186-7_9.

Gelman, A. and J. Hill. 2006. Data Analysis Using Regression and Multilevel/Hierarchical Models. Cambridge: Cambridge University Press, https://doi.org/10.1017/CBO9780511790942.

Goldthorpe, J. H. 2009. ‘Understanding the Role of Education in Intergenerational Class Mobility: Some Pointers for Sociologists from Labour Economics.' Unpublished Manuscript.

Goldthorpe, J. H. 2014. 'The Role of Education in Intergenerational Social Mobility: Problems from Empirical Research in Sociology and Some Theoretical Pointers from Economics.' Rationality and Society 26 (3): 265-289, https://doi.org/10.1177/1043463113519068.

Goos, M., A. Manning and A. Salomons. 2014. 'Explaining Job Polarization: RoutineBiased Technological Change and Offshoring.' American Economic Review 104 (8): 2509-2526, https://doi.org/10.1257/aer.104.8.2509.

Heckman, J. J., L. J. Lochner and P. E. Todd. 2006. 'Earnings Functions, Rates of Return and Treatment Effects: The Mincer Equation and Beyond.' Handbook of the Economics of Education 1: 307-458, https: // doi.org/10.1016/S1574-0692(06)01007-5.

Hirsch, F. 1978. Social Limits to Growth. London: Routledge \& Kegan Paul.

Hout, M. 2012. 'Social and Economic Returns to College Education in the United States.' Annual Review of Sociology 38: 379-400, https://doi.org/10.1146/annurev.soc.012809.102503.

ILO (International Labour Office). 1968. 1988. 2008. International Standard Classification of Occupations. Geneva: International Labour Office.

Jackson, M., J. H. Goldthorpe and C. Mills. 2005. 'Education, Employers and Class Mobility.' Research in Social Stratification and Mobility 23: 3-33, https://doi.org/10.1016/S0276-5624(05)23001-9.

Keeley, B. 2007. Human Capital: How What You Know Shapes Your Life. Paris: OECD Publishing, https://doi.org/10.1787/9789264029095-en.

Kerckhoff, A. C., S. W. Raudenbush and E. Glennie. 2001. 'Education, Cognitive Skill, and Labor Force Outcomes.' Sociology of Education 74 (1): 1-24, https://doi.org/10.2307/2673142.

Kivinen, O. and S. Ahola. 1999. 'Higher Education as Human Risk Capital.' Higher Education 38 (2): 191-208, https://doi.org/10.1023/A:1003788929925.

Kogan, I. 2012. 'Tertiary Education Landscape and Labour Market Chances of the Highly Educated in Central and Eastern Europe.' European Sociological Review 28 (6): 701-703, https://doi.org/10.1093/esr/jcs062.

Kreft, I. G. G. and J. De Leeuw. 1998. Introducing Multilevel Modeling. London: Sage Publications, https://doi.org/10.4135/9781849209366.

Manning, A. 2004. 'We Can Work It Out: The Impact of Technological Change on the Demand for Low-Skill Workers.' Scottish Journal of Political Economy 51 (5): 581-608, https://doi.org/10.1111/j.0036-9292.2004.00322.x.

Manning, A. and F. Saidi. 2010. 'Understanding the Gender Pay Gap: What's Competition Got to Do with It?' ILR Revieww 63 (4): 681-698, https://doi.org/10.1177/001979391006300407.

Mincer, J. 1958. 'Investment in Human Capital and Personal Income Distribution.' Journal of Political Economy 66 (4): 281-302, https://doi.org/10.1086/258055. 
Mincer, J. 1974. Schooling, Experience, and Earnings. New York: National Bureau of Economic Research.

Morrison Paul, C. and D. Siegel. 2001. 'The Impacts of Technology, Trade and Outsourcing on Employment and Labor Composition.' The Scandinavian Journal of Economics 103 (2): 241-264, https://doi.org/10.1111/1467-9442.00243.

Nelson, R. R. and E. S. Phelps. 1966. 'Investment in Humans, Technological Diffusion, and Economic Growth.' The American Economic Review 56 (1-2): 69-75.

OECD. 2019. Population with Tertiary Education (Indicator). Paris: OECD.

Oesch, D. and J. Rodríguez-Menés. 2010. 'Upgrading or Polarization? Occupational Change in Britain, Germany, Spain and Switzerland, 1990-2008.' Socio-economic Review 9 (3): 503-531, https://doi.org/10.1093/ser/mwq029.

Oesch, D. 2013. Occupational Change in Europe: How Technology and Education Transform the Job Structure. Oxford: Oxford University Press, https://doi.org/10.1093/acprof:oso/9780199680962.001.0001.

Olneck, M. R. and K.-S. Kim. 1989. 'High School Completion and Men's Incomes: An Apparent Anomaly.' Sociology of Education 62 (3): 193-207, https:// doi.org/10.2307/2112867.

Ortiz, L. and J. Rodriguez-Menés. 2016. 'The Positional Values of Education and Its Effect on General and Technical Fields of Education: Educational Expansion and Occupational Returns to Education in Spain.' European Sociological Review 32 (2): 216-237, https://doi.org/10.1093/esr/jcv085.

Pallas, A. M. 2006. 'The Effects of Schooling on Individual Lives.' Pp. 499-525 in Handbook of the Sociology of Education, edited by M. T. Hallinan. Berlin: Springer, https://doi.org/10.1007/0-387-36424-2_23.

Peet, E. D., G. Fink and W. Fawzi. 2015. ‘'Returns to Education in Developing Countries: Evidence from the Living Standards and Measurement Study Surveys.' Economics of Education Review 49 (C): 69-90, https://doi.org/10.1016/j.econedurev.2015.08.002.

Rabe-Hesketh, S. and A. Skrondal. 2012. 'Multilevel and Longitudinal Modeling Using Stata.' College Station, TX: Stata Press.

Ross, C. E. and C.-L. Wu. 1995. 'The Links between Education and Health.' American Sociological Review 60 (5): 719-745, https://doi.org/10.2307/2096319.

Rotman, A., Y. Shavit and M. Shalev. 2016. 'Nominal and Positional Perspectives on Educational Stratification in Israel.' Research in Social Stratification and Mobility 43: 17- 24, https://doi.org/10.1016/j.rssm.2015.06.001.

Shavit, Y. and W. Müller. (eds) 1998. From School to Work. A Comparative Study of Educational Qualifications and Occupational Destinations. Oxford, UK: Clarendon Press.

Spence, M. 1973. 'Job Market Signaling.' Quarterly Journal of Economics 87 (3): 355-374, https://doi.org/10.2307/1882010.

Thurow, L. C. 1975. Generating Inequality: Mechanisms of Distribution in the US Economy. New York: Basic Books.

Trow, M. 1973. Problems in the Transition from Elite to Mass Higher Education. Berkeley, CA: Carnegie Commission on Higher Education.

Ultee, W. C. 1980. 'Is Education a Positional Good-An Empirical Examination of Alternative Hypotheses on the Connection between Education and Occupational Level.' Netherlands Journal of Social Sciences 16 (2): 135-153.

Van de Werfhorst, H. G. and R. Andersen. 2005. 'Social Background, Credential Inflation and Educational Strategies.' Acta Sociologica 48 (4): 321-340, https://doi.org/10.1177/0001699305059945. 
Vila, L. E. 2000. 'The Non-Monetary Benefits of Education.' European Journal of Education 35 (1): 21-32, https://doi.org/10.1111/1467-3435.00003.

Weiss, A. 1995. 'Human Capital vs Signalling Explanations of Wages.' Journal of Economic Perspectives 9 (4): 133-154, https://doi.org/10.1257/jep.9.4.133.

Welch, F. 1970. 'Education in Production.' Journal of Political Economy 78 (1): 35-59, https://doi.org/10.1086/259599. 


\section{Appendix}

Table A1. The numbers of respondents analysed in individual countries and years

\begin{tabular}{|c|c|c|c|c|}
\hline \multirow[b]{2}{*}{ Country } & \multicolumn{3}{|c|}{ Year } & \multirow[b]{2}{*}{ Total } \\
\hline & 2014 & 2015 & 2016 & \\
\hline Austria (AT) & 13193 & 13645 & 14680 & 41518 \\
\hline Belgium (BE) & 8319 & 8600 & 8983 & 25902 \\
\hline Bulgaria (BG) & 1775 & 1702 & 2211 & 5688 \\
\hline Croatia (HR) & 6189 & 6252 & 5591 & 18032 \\
\hline Cyprus (CY) & 3694 & 3861 & 3919 & 11474 \\
\hline Czech Republic (CZ) & 2792 & 3007 & 3164 & 8963 \\
\hline Denmark (DK) & 42427 & 44940 & 48553 & 135920 \\
\hline Estonia (EE) & 8904 & 9022 & 7214 & 25140 \\
\hline Finland (FI) & 2168 & 2322 & 2389 & 6879 \\
\hline France (FR) & 6475 & 7054 & 6428 & 19957 \\
\hline Germany (DE) & 4258 & 4398 & 4190 & 12846 \\
\hline Greece (GR) & 33586 & 35666 & 37930 & 107182 \\
\hline Hungary (HU) & 2455 & 2732 & 2260 & 7447 \\
\hline Iceland (IS) & 16300 & 17270 & 17100 & 50670 \\
\hline Ireland (IE) & 17610 & 15840 & 13706 & 47156 \\
\hline Italy (IT) & 1649 & 1658 & 1296 & 4603 \\
\hline Latvia (LV) & 27705 & 30586 & 31807 & 90098 \\
\hline Lithuania (LT) & 3912 & 3998 & 4204 & 12114 \\
\hline Luxembourg (LU) & 1044 & 2926 & 2381 & 6351 \\
\hline Netherlands (NL) & 2974 & 3023 & 3217 & 9214 \\
\hline Norway (NO) & 1654 & 1788 & 1869 & 5311 \\
\hline Poland (PL) & 6433 & 5895 & 5537 & 17865 \\
\hline Portugal (PT) & 2357 & 2412 & 2491 & 7260 \\
\hline Romania (RO) & 32104 & 30835 & 29314 & 92253 \\
\hline Slovakia (SK) & 9425 & 9766 & 9422 & 28613 \\
\hline Slovenia (SI) & 13007 & 16893 & 17178 & 47078 \\
\hline Spain (ES) & 30856 & 30147 & 25712 & 86715 \\
\hline Sweden (SE) & 5809 & 5690 & 5636 & 17135 \\
\hline Switzerland $(\mathrm{CH})$ & 7174 & 7771 & 8005 & 22950 \\
\hline United Kingdom (UK) & 6567 & 6414 & 6607 & 19588 \\
\hline Total & 322815 & 336113 & 332994 & 991922 \\
\hline
\end{tabular}

Source: Labour Force Survey (LFS). 
Table A2. Variables included in the analysis—first part

\begin{tabular}{|c|c|c|c|}
\hline Variable & EU LFS item & $\begin{array}{c}\text { Question wording / } \\
\text { description }\end{array}$ & Values after transformation \\
\hline \multicolumn{4}{|l|}{ Individual level } \\
\hline ISEI & ISCO3D & $\begin{array}{l}\text { Occupation coded } \\
\text { on } 3 \text { digits ISCO-08 }\end{array}$ & $\begin{array}{l}\text { Transformation into ISEI codes } \\
\text { (range: } 11.01 \text { - 88.70). }\end{array}$ \\
\hline Gender & SEX & & 1-man; 2-woman \\
\hline Marriage & MARSTAT & & 1-other; 2 -married \\
\hline Full-time job & FTPT & $\begin{array}{l}\text { Full-time / part- } \\
\text {-time distinction }\end{array}$ & 1-part-time; 2-full-time job \\
\hline $\begin{array}{l}\text { Education } \\
\text { in years } \\
\text { (standardised) }\end{array}$ & HATLEVEL & $\begin{array}{l}\text { Highest educational } \\
\text { attainment level: } \\
\text { ISCED } 11 \text { codes } \\
(0,100,200,300 \ldots \\
800) .\end{array}$ & $\begin{array}{l}\text { Transformation ISCED } 11 \text { co- } \\
\text { des into years in educational } \\
\text { system }(0-304=12 ; \\
400-500=14 ; 600=16 ; \\
700=18 ; 800=20) \\
\text { standardisation of variable } \\
(\text { mean }=0 ; \mathrm{SD}=1)\end{array}$ \\
\hline $\begin{array}{l}\text { Education in } \\
\text { percentiles } \\
\text { (standardised) }\end{array}$ & HATLEVEL & $\begin{array}{l}\text { Highest educational } \\
\text { attainment level: } \\
\text { ISCED } 11 \text { codes } \\
(0,100,200,300 \ldots \\
800) .\end{array}$ & $\begin{array}{l}\text { Transformation ISCED } 11 \\
\text { codes into years in educational } \\
\text { system }(0=1 ; 100=7 ; 200=9 ; \\
302=12 ; 300,303,304=13 ; \\
400=14 ; 500=15 ; 600=16 ; \\
700=18 ; 800=22) ; \text { trans- } \\
\text { formation into proportional } \\
\text { scores (percentiles) for each } \\
\text { countrycohort combination; } \\
\text { standardisation of proportion } \\
\text { variable (mean }=0 ; \mathrm{SD}=1 \text { ) }\end{array}$ \\
\hline Study fields & HATFIELD & $\begin{array}{l}\text { Highest educati- } \\
\text { onal attainment } \\
\text { field: ISCED } 97 \text { and } \\
\text { ISCED } 11 \text { codes } \\
(0,10,20 \ldots 100,200 \text {, } \\
300 \ldots 888) \text {. }\end{array}$ & $\begin{array}{l}\text { Recoded into } 6 \text { categories: } \\
(0888900 .=1, \text { unspecified/ } \\
\text { general); }(10 / 40100 / 300 \\
301 / 399800801 / 863=2, \text { edu- } \\
\text { cation/social/services); } \\
(50 / 60400 / 482=3, \text { natural/ } \\
\text { computer /IT); (70 500 501/599 } \\
=4, \text { engineering/constructi- } \\
\text { on); } 80600601 / 699=5 \text {, agri- } \\
\text { culture/forestry/veterinary); } \\
(90700701 / 799=6, \text { health/ } \\
\text { welfare })\end{array}$ \\
\hline
\end{tabular}


Table A2. Variables included in the analysis—second part

\begin{tabular}{|c|c|c|c|}
\hline Variable & EU LFS item & $\begin{array}{c}\text { Question wording / } \\
\text { description }\end{array}$ & Values after transformation \\
\hline \multicolumn{4}{|l|}{ Contextual level } \\
\hline $\begin{array}{l}\text { Educational } \\
\text { expansion by } \\
\text { cohorts }\end{array}$ & -- & $\begin{array}{l}\text { Proportion of } \\
\text { people with tertiary } \\
\text { education for each } \\
\text { country and cohort } \\
\text { (defined by the } \\
\text { year of leaving the } \\
\text { education system) } \\
\text { indicated by ISCED } \\
2011 \text { ( } 5-8 \text { levels) for } \\
\text { age group } 25-34 \text {; } \\
\text { data come from } \\
\text { Eurostat. }\end{array}$ & $\begin{array}{l}\text { Proportion of people with ter- } \\
\text { tiary education in the } 30 \text { coun- } \\
\text { tries analysed and } 12 \text { gradua- } \\
\text { ted cohorts } 2003-2014 \text { indica- } \\
\text { ted by ISCED } 2011 \text { ( } 5-8 \text { levels) } \\
\text { for age group } 25-34 \text {. }\end{array}$ \\
\hline
\end{tabular}

